This item was submitted to Loughborough's Institutional Repository (https://dspace.lboro.ac.uk/) by the author and is made available under the following Creative Commons Licence conditions.

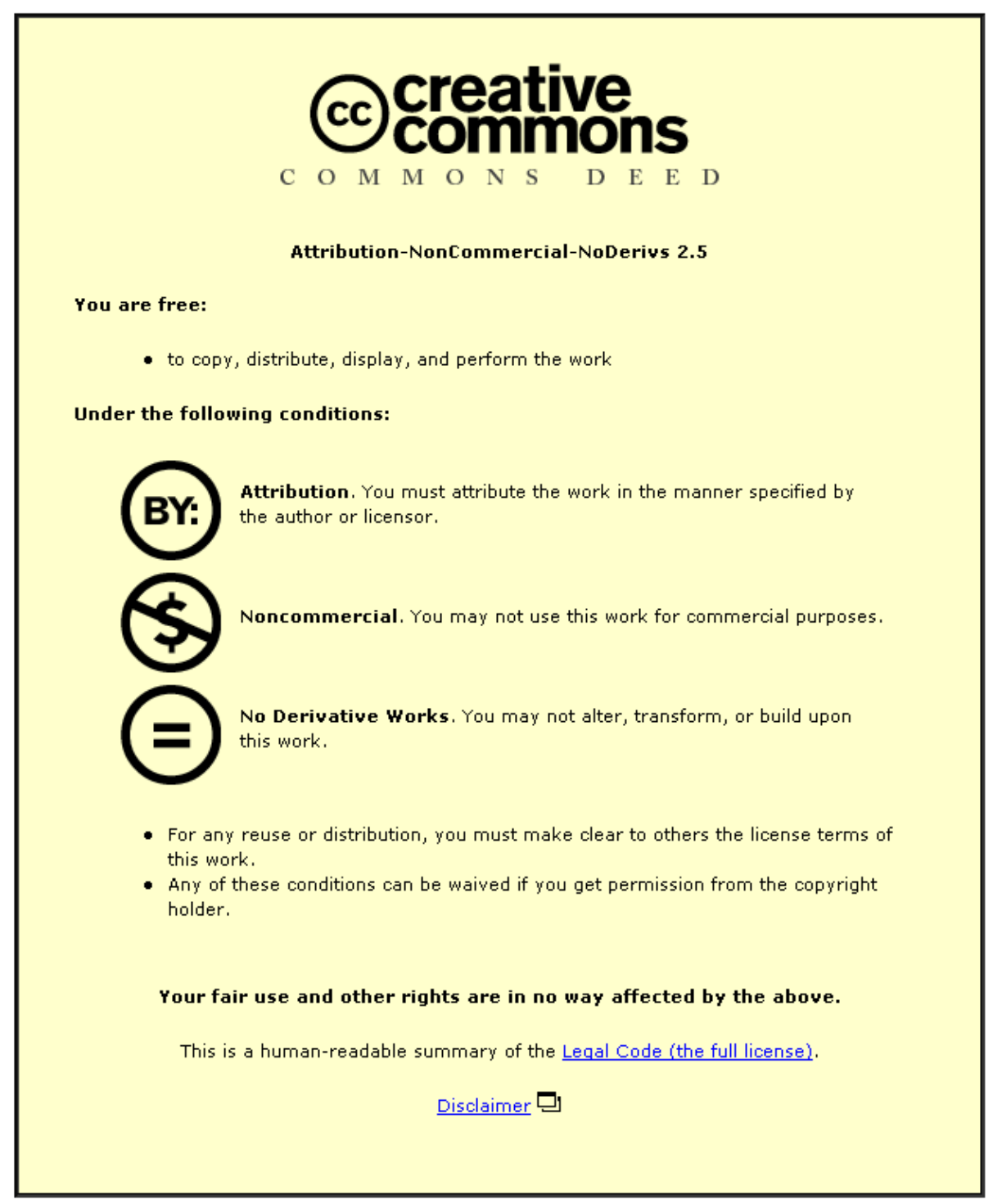

For the full text of this licence, please go to: http://creativecommons.org/licenses/by-nc-nd/2.5/ 


\title{
Building networks to work: An ethnographic study of informal routes into the UK construction industry and pathways for migrant up-skilling
}

\author{
DYLAN TUTT, SARAH PINK, ANDY R.J. DAINTY and ALISTAIR GIBB \\ Construction Management and Economics, 2013, http://dx.doi.org/10.1080/01446193.2013.834066
}

\begin{abstract}
The UK construction industry labour market is characterised by high levels of self-employment, subcontracting, informality and flexibility. A corollary of this, and a sign of the increasing globalisation of construction, has been an increasing reliance on migrant labour, particularly that from the Eastern European Accession states. Yet, little is known about how their experiences within and outside of work shape their work in the construction sector. In this context better qualitative understandings of the social and communication networks through which migrant workers gain employment, create routes through the sector and develop their role/career are needed. We draw on two examples from a short-term ethnographic study of migrant construction worker employment experiences and practices in the town of Crewe in Cheshire, UK, to demonstrate how informal networks intersect with formal elements of the sector to facilitate both recruitment and up-skilling. Such research knowledge, we argue, offers new evidence of the importance of attending to migrant worker's own experiences in the development of more transparent recruitment processes.
\end{abstract}

Keywords: Migrant Workers; Employment; Ethnography; Labour Markets

Building networks to work: An ethnographic study of informal routes into the UK construction industry and pathways for migrant up-skilling

\section{Introduction}

The UK construction industry's employment and industrial relations climate is characterised by a reliance on informal and casualised employment practices which provide low barriers to entry for those wanting to work within the sector. As well as a reliance on contingent, self-employed and undeclared labour, the industry has increasingly drawn on migrant labour to fill skills gaps within the labour market, especially since the accession of Eastern European countries into the EU in 2004. This has become a highly contested public policy issue (Anderson et al. 2006), as although it has benefitted the UK economy, the cultural diversity that migration generates presents challenges for employers and for migrant welfare. However, whilst such workers have undoubtedly found routes to employment within the industry, relatively little emphasis has been placed on understanding their experiences and the implications for their welfare and integration into the sector. There is a lack of knowledge around the potential risks and opportunities posed by these (informal) labour markets and patterns of migration. As such, there is a need to better understand the social and communication networks within which migrant workers become embedded, and how these play out within the construction labour market context. In this article we address this issue through an analysis of how migrants' experiences of their formal and informal working lives and social relationships impact on their routes through the construction sector and their role/career development. In doing so we draw on ethnographic research in the UK construction industry which has enabled us to create a focused account of migrant worker socialities, that is the qualities and types of social relationships that develop around activities when people are 'brought together' (see Pink, 2008), whether through situated or virtual interactive practices. 


\section{Context}

For many years the UK construction industry has struggled to reproduce high-quality skills (Clarke 2006; Chan and Dainty 2007). Arguably, it is the regulatory context, or rather the de-regulated nature of the construction labour market that has shaped this picture (Chan and Dainty 2007). The shift in regulation has arguably led the industry down what has been coined the "low road" development path (Harvey 2003: 188). Within this model, low-skill and low-wage strategies predominate, along with mass scale selfemployment and complex subcontracting chains. Employment practices are typically informal, with a tendency to rely on existing networks rather than formal routes (Chan et al. 2010: 242). A corollary of this has been an increasing reliance on migrant labour. The HSE (2010) estimated that migrant labour makes up $8.2 \%$ of the labour force in the UK construction industry, but there is huge regional and localised variation with the percentage rising to $18 \%$ in London and the South East, and migrants account for around 37\% of the workforce in Greater London according to the 2009 Survey of Construction Workers (HSE, 2010). Between May 2004 and April 2011, A8 nationals working in the UK for more than a month were required to register under the Worker Registration Scheme (WRS). The comparison of WRS registrations (May 2004 - June 2010) to the total number of employees working in construction indicates a relatively low percentage (2.9\%) of A8 workers to total employee jobs. However these figures are misleading since self-employed workers were exempt from registration and, as McCollum and Findlay (2011) explain, many A8 migrants appeared from the data to be working in the administration, business and management sector (42\% of all registrations), when most migrants recorded in this group were actually employed by recruitment agencies or labour providers. This means that "their employment, far from being in 'business', usually involved working under contract for their employers in other parts of the economy" such as the construction and agriculture industries (p. 4). So called 'bogus self-employment' is used by many employers and the trades unions argue that the motivation is "to evade taxes and engage workers without having to respect employment rights and entitlements such as holiday pay, sick pay and pensions", with the union UCATT (2012) estimating that over $50 \%$ of those working in the industry are falsely self-employed.

Given the apparent scale of inward migration to the sector, and concerns over the industry's employment practices, there is a need for a more informed understanding of the experiences of migrant workers in the UK construction industry, and the ways in which these patterns of migration play out within the industry's informal labour market context. This demands an understanding of migrant workers' experiences, both in terms of how they find and sustain work via social and communication networks, and in their experiences of working within the sector.

Our applied research had investigated health, safety and welfare issues in the context of communication between and amongst non/low English-speaking construction workers and English-speaking site managers (Tutt et al., 2010, 2012). As McKay et al. (2006) reveal, migrant workers are more likely to be at risk given their status as new workers, their differential experiences of safety and health in their own countries, communication difficulties and lack of knowledge of their legislative rights. Thus, the original objective of our research was to better understand how such workers were integrated into the sector and managed their personal health and safety on a day-to-day basis, and aimed to inform and evaluate the production of training and other materials to support such communication. Yet while the main focus of this project was onsite activities (see Tutt et al., 2013), it was also evident from our research that migrants' practices on construction sites are inextricable from offsite recruitment practices as well as local government and non-governmental welfare contexts. Existing research with Polish migrants in London also shows how ethnic ties can be advantageous in seeking jobs and social support, but also reveals concerns about exploitation by Polish employers in the construction industry (Eade et al., 2007). Thus, it was important that our study sought to investigate this context through a focus on the intersections and continuities between onsite and offsite processes, socialities and practices.

This paper illuminates some of the informal routes to construction work, the social and communication networks which migrant workers use, and the implications in terms of the health, safety and welfare of migrant workers. We first draw on an example of local access to construction work and training (through local/kinship networks). This brought to our attention the significance of the processes (local and transnational; official and unofficial) through which migrant construction workers are recruited and which influence their occupational mobility (and up-skilling). We then examine two specific examples of how migrant workers developed routes and careers through the sector. We look at the experiences of an 
agency worker, Artur, who developed an informal translator role into a permanent job with the main contractor, and Lukasz, who needed to balance his translation and interpretation responsibilities, in a secondary role, with the ongoing site work [1]. This research demonstrates how informal networks intersect with formal elements of the sector in the utilisation of language skills and worker engagement in health and safety on site, and stresses the importance of attending to migrant worker's own experiences in the development of more transparent recruitment processes. First we outline further how migration was a context for our research.

\section{Liquid migration, pendulum migration and drifters: Patterns of economic migration}

Migration is a complex phenomenon and is often not easy to understand without a close focus on what migrants actually do and how they comprehend their experiences. Flint (2008), speaking at the Polish Embassy, stressed the more fluid and flexible patterns which are developing in modern economic migration. This includes what she refers to as 'pendulum' migration, with people swinging back and forth between different countries, moving in response to demand for labour and leaving again when employment conditions become less flexible or when the home situation improves. Indeed, there has been disagreement on the extent of reverse immigration of East European workers since the recession, as well as some data pointing to significant increases in migrant workers returning to the UK from second quarter of 2010 (Migration Information Source, 2011). Favell (2008) describes East European migrants as regional "free movers" who are more likely to engage in temporary circular and transnational mobility than long-term permanent immigration. His qualitative research indicates that both highly-skilled and lowerskilled workers who are drawn to the West tend to "see their movements as temporary, opportunistic and circular" and can commonly experience exclusion and exploitation as they accept "sharp downward [occupational] mobility in terms of status and qualifications" in order to enter the labour market (p. 711) . However, he also notes elsewhere (Favell and Recchi, 2011: 74) the evidence of the accompanying "distinct social mobility, income improvement, and return development effects" among East European migrants in relation to their situation prior to migration. The term 'liquid migration' was coined by Engbersen et al. (2010: 117) to refer to the "complex, transitory and temporary patterns of transnational work and settlement". This fluidity and circulatory nature of migration, and the mobility and shifting priorities of migrants, makes the patterns and the temporal and spatial detail of these movements difficult to predict. While analysing demographic behaviour, such as the bringing over of families and children from Poland, is a strong indication, it is very difficult to assess how temporary or permanent a migration phenomenon is. As Engbersen et al. (2011) explain, "asking immigrants whether it is their intention to stay is not a very useful method, since most of them do not know what the future will hold" (p.126).

Not only are migrant experiences then unpredictable, but also varied. Lett and Smith (2009) examine the experience of newly migrating Poles into the UK, in the sense of skilled professionals sent abroad by their companies. They argue that the economic and social benefits of this migration - particularly improved standard of living, educational opportunities and greater organisational freedom - can help these 'expatriates' overcome different adjustment pressures, such as the long-hours culture. However, while they offer insight into the individual experiences of Polish migrant workers, these understandings are strictly reserved for those employed in top level managerial jobs working for Polish-based companies in the UK. For more typical skilled and non-skilled migrant workers, pre-accession migrants had few options but to take up work in the informal sector. Post-2004, the common gravitation of often highly educated A8 migrants towards low-skilled jobs in the UK, in addition to the financial pressure for them to find work quickly, has been linked to factors such as registration regulations, problem of diploma recognition and the structure of labour demand and supply (Currie, 2007; Trevena, 2011a).

However, it is possible to construct some workable categories within this context. For instance, Trevena (2011b) untangles the desire of some migrants for up-skilling and career advancement ('or career seekers') from other motivations for migration, with her categorisation of 'drifters' entering the job market for the experience of living abroad, learning the language, travelling etc., and 'target earners', which she found common to the construction industry, who want the flexibility to undertake the best-paid low-skilled work. Such categories of motivations are, of course, also fluid in practice. Indeed, the experiences of Lukasz and Artur - discussed later in the paper - demonstrate how the boundaries between the typologies 
frequently merge and blur as Polish migrants embark on the everyday realities of living in the UK and working in construction.

The liquidity of these migration flows is also somewhat reflected, or perhaps enhanced, by the longstanding and distinct peculiarities of construction work. For example, migrant workers will inevitably experience transient (and most probably itinerant) working practices inherent in the temporality of projects and project-based working. Moreover, as we discuss in this paper, migrant workers may not actually live in the area where they found work. Their routes to work, even if sought out through local networks, may actually lead them into living (at least temporarily) away in other areas. Indeed, construction has long been a migratory industry, and, as an interviewee in Chappell et al's (2008) Economics of Migration project explains, "workers have always moved to where the work is, because the work moves around" ( $p$. 47).

For 'pendulum' migrant workers, who frequently move or commute between countries, Niedzwiedzki (2008) notices how the process of identity reconstruction is different to that of 'classical' migrants making a more structured or permanent move. In his qualitative study of the social identity of Polish migrants' in Belgium, he describes many pendulum migrants as occupying "somewhere between the 'old' (before migration) and 'new' (after migration) cultural worlds they find themselves in" (p. 565). Indeed, the different levels of integration of Polish labour migrants in the host and home countries is picked up by Engbersen et al. (2011) who have developed a categorisation based around the strength of workers' attachment to the home country and destination country, arguing that the new individualised 'liquid' migration patterns are indicating a shift to a more footloose migration. However, while Niedzwiedzki (2008) picks up on some of the cultural reasons behind why some of these migrants are "working on the black market" and avoiding contact with official institutions, a fuller picture of typical working lives and movements along their career trajectories are absent from this picture.

These accounts therefore offer us a series of understandings and frameworks for contemporary migration that the experiences of Polish migrant workers in the construction industry touch on and can be compared to. Yet, we will show, by exploring the routes that individuals follow we can gain stronger insights into how their situations are actually framed.

\section{Following routes to work and training in the sector: An ethnographic approach}

Our fieldwork was multi-sited, covering ten construction sites across the UK including different sized projects run by a variety of principal contractors. This involved using contextually appropriate ethnographic methods contingent on the opportunities and emergent phenomena on each site, but included combinations of: intensive study/'shadowing' of workers; participant observation of workers at key areas on construction sites (including site inductions, canteens, sites of specific trades etc.); informal interviews with migrant workers and co-workers; formal interviews with health and safety managers/directors and site managers; data collection of hazard report cards, site safety books, photographs and other visual materials (e.g. work activity, signs, site safety league tables).

Ethnography is now emerging as part of the repertoire of approaches to understanding the construction industry. Construction ethnography as a field of practice can offer new routes to knowledge, but need not be informed by a single methodological approach, or as necessarily producing one particular type of scholarly or applied knowledge (see Pink et al., 2012). Ethnography is a methodology that develops in practice and, as defined in the 'classic' approaches to ethnography (e.g. as discussed by Atkinson et al., 2007), involves combinations of observing behaviours, participating in activities, writing extensive notes, interviewing and reflecting on one's own role in the research process. However, situations where longterm fieldwork in one location for extended periods might not be viable demand alternative approaches to both theoretical and technological developments. Construction sites - and the way they are experienced - are also shaped by the individuals and groups who are involved in them, even if in some cases their stays are short. This makes for a dynamic and theoretically fascinating research context. Yet it also creates challenges in terms of how one might go about researching an environment where often everyday temporalities are dominated by transience. In a practical sense it raises the question of how to do research with mobile participants in a transient world - involving dispersed sites and persons, and constantly changing materialities and sensory aesthetics. 
These newer ethnographic approaches also differ to traditional long-term fieldwork in that the nature of the participation that they involve changes. They often use participatory and collaborative photographic, video-based and other techniques, to enable ethnographers to better understand other people's experiences, and to generate closer and empathetic understandings of these experiences in contexts of analysis and dissemination (see Pink, 2009). Employing these ethnographic methods, then, offers the potential to produce detailed understandings in research contexts that exhibit the constraints of the construction industry (e.g. the temporal nature of projects and the involvement of their actors in different localities, or their movements between and within places) (see Pink et al., 2012; Marshall and Bresnen, 2012).

Recently, calls for a greater use of ethnographic methods have been provided with new emphasis by the emerging acceptance of the value of 'practice' perspectives. This 'practice-turn' in organisation studies (see Bresnen, 2009), with its implications for situated learning and knowing in practice (see Gherardi and Nicolini, 2002), has the potential to illuminate construction practice in new ways if informed by 'thick' ethnographic description. In particular, common perceptions of the industry might be challenged through an attendant focus on local contexts, practices and differences that ethnographic research brings to the fore. Deeper understandings of the realities and lived experiences of those within the industry would enable problems to be reframed in ways which account for both the specificities of the contexts to which they relate and the socialities, materialities and experiences through which they unfold.

The wider research project sought to better understand how such workers were integrated into the sector and managed their personal health and safety on a day-to-day basis, but it has implied that migrants' practices on construction sites are inextricable from off-site recruitment processes, socialities and practices. Promoted by our questions about the back stories of East European migrant workers who we were meeting in site inductions on construction sites as part of the project, we developed a small-scale and exploratory ethnographic study of some of the off-site experiences and practices of migrant construction workers in the town of Crewe in Cheshire. We wanted to investigate some of these continuities on site, but researching migrant workers' experiences in the construction industry is particularly methodologically challenging. Labour is employed contingently through subcontracting chains and construction is also one of the main sectors for undeclared migrant labour (McKay et al., 2006), which evades official labour market statistics (See Gribling and Clarke, 2006). Plus, with the existing applications for National Insurance numbers based only on area of residence, there is mismatch between the numbers of migrant construction workers living and working within the North West region of the UK, where the town of Crewe is based (Pemberton, 2006).

Migrant construction workers constitute an often short term, diverse and mobile workforce, and may travel to work in vans organised by recruiters, move from site to site regularly or move between regions according to geographical demand. Given this mobility, we decided to make the starting point for this ethnographic research key sites in the Polish 'community' or other emerging in/formal avenues to work onsite. In practice, this consisted of periods of participant observation and informal interviews at: a Polish delicatessen and forecourt notice board of community and recruitment agencies' adverts and events; the Polish Association offering an internet café and drop-in service for advice and contact with housing, recruitment, and welfare services; the Polish Pub; and ad hoc construction worker 'pick up' spots along Nantwich Road, the main road between the towns of Crewe and Nantwich. This chain of information, with one contact leading to other key contacts across the Polish community, was also representative of some of the available and informal routes to work in Crewe, or rather of chains which had been structured linking focal centres in the Polish community. Drawing also on our material data collection (posters/adverts/local media report etc.), this research, as we will demonstrate, hints at a rich avenue of construction recruitment information which often lies under-researched, including informal opportunities for up-skilling developed both on-site and off-site.

\section{Mutual Aid: the role of existing Poles in the community}

While there has been a Polish community in Crewe since the Second World War, approximately 6,000 Polish migrants have moved to the town since Poland entered the EU in May 2004. Cheshire police estimated that Polish economic migrants made up $10 \%$ of the town's population in 2008. Migrant workers in Crewe are frequently recruited, often via agencies in Poland, to work outside the borough. An 
established Polish community has worked as a strong draw for the newly migrating Polish workers, irrespective of the debates about how strong the actual relationships and support links between these generations are within the community. Crewe is identified as a town where migrant 'community' associations exist and where there is demonstrated capacity for involving migrants in local consultation and for service providers to access migrant workers directly (Pemberton, 2006). The Borough Council and Cheshire Police received nationwide acclaim for their welfare provision in response to the growth of Polish migrants in Crewe (Audit Commission, 2007; National Justice Awards, 2007). This included setting up the Polish Association and Steering Group, and forging links with local employment agencies and the specialist shops and businesses that have developed with the Polish community.

Fitzgerald (2007) also highlights examples of union branches in the North West developing organising strategies to reach out effectively to Polish migrant workers, but argues that these have much to learn from Polish community-based organisations. North West UCATT union officials stressed the importance of these support networks in terms of negotiating employment problems related to agencies, which were playing a key role given the lack of direct or sub-contractor recruitment. For instance, a combination of community groups working through the Polish church and a Manchester-federated branch of the ZPWB (Federation of Poles in Great Britain) were uniting to help with employment status and issues in the surrounding areas (Fitzgerald, 2007: 8).

Brown (2006: 47) attributes the high amount of Polish migrants in the UK, since the accession to the EU, to the newly arriving Poles' "ability to find jobs, accommodation and a niche in this society", success which she suggests is "due to the density of Polish social networks and the expectation of reciprocity". Here, in our Crewe study, we are able to consider this system of mutual aid, which Brown (2006) describes as "an adaptation of a traditional social form into something new", in which 'friends', more so than family, provide contacts in the UK from which networks of social contacts continue to grow. This system is based not just on personal acquaintance but on shared nationality and common aims (e.g. to minimise cost of rent, and maximise income) (p.47). The nature of 'chain migration' amongst new Polish migrants, in which people from the same home communities have tended to migrate en masse to the same UK destinations and often known to fellow migrants from their home towns and villages, is well documented but the actual strength and importance of friendship in these moves is often unclear (Mandic, 2008).

The role of older Polish generations - in the offsite processes for gaining work onsite - is also often complex. On the one hand, such routes to UK construction do exist, especially in terms of taking the first step on site. Other research with Polish migrants in London indicates that while ethnic ties can be advantageous in seeking jobs and social support, there are concerns about exploitation by Polish employers in the construction industry over the long-term (Eade et al. 2007). While the previous generations of Polish migrants offer a level of community support to newcomers that is simply not developed among Romanians in the UK, we will see how this is more of an indirect or informal role in practice, in the sense that, as Brown (2006) explains, "these older Poles established cafes, shops, the Polish Institute (POSK) and churches for their community - all of which help to provide an institutional structure through which networks can thrive" (p. 48). We will now briefly discuss how these specialist Polish shops have acted as a vital portal of information in Crewe's Polish community for migrant workers looking to enter into the UK Construction industry. However, under closer examination, following these routes to work and up-skilling in the shop window can be also be seen to fit in line with patterns of liquid migration and increased mobility.

\section{Informal routes to work: Polish food shops and establishments}

The diversity and equality officer for East Cheshire described the specialist Polish shops in Crewe as being "an absolute godsend for getting messages out to the Polish community" (Hughes, 2008). This was echoed in the Audit Commission's (2007) report on public service response to the local challenges of migrant workers in the Crewe and Nantwich borough, where the Council and the police's links with publicans, employers and local employment agencies are identified as part of the longer-term strategy. We would like to first concentrate on one chain of information in Crewe's Polish community, which links together migrant workers, Polish Food stores, the Polish pub, personnel/agency and welfare links, and 
ultimately construction work onsite. Despite this apparently local focus, we will then look at how the network reaches out of the geographical locality.

While there is a much clearer and well established structure to employment of Polish migrants now (agencies, housing, council links) compared to in 2004, the Polish shops still play a big part in the community. This additional role, of providing a service to the community in addition to the trade, is far from unique to Crewe. Brown (2006: 48), for example, also describes 'The Wailing Wall' "an advertising site located at a newsagent outside the Polish Institute which is a first port of call for flats and jobs for many Poles". In Figure 1, a large poster (translated on the right-hand side) is placed prominently in the window of a Polish food store, advertising an open day hosted (collaboratively) by Ludzie Personnel recruitment agency and consultancy, MOLE labour recruitment, and Pathway Estates investment and lettings at the Polish pub.

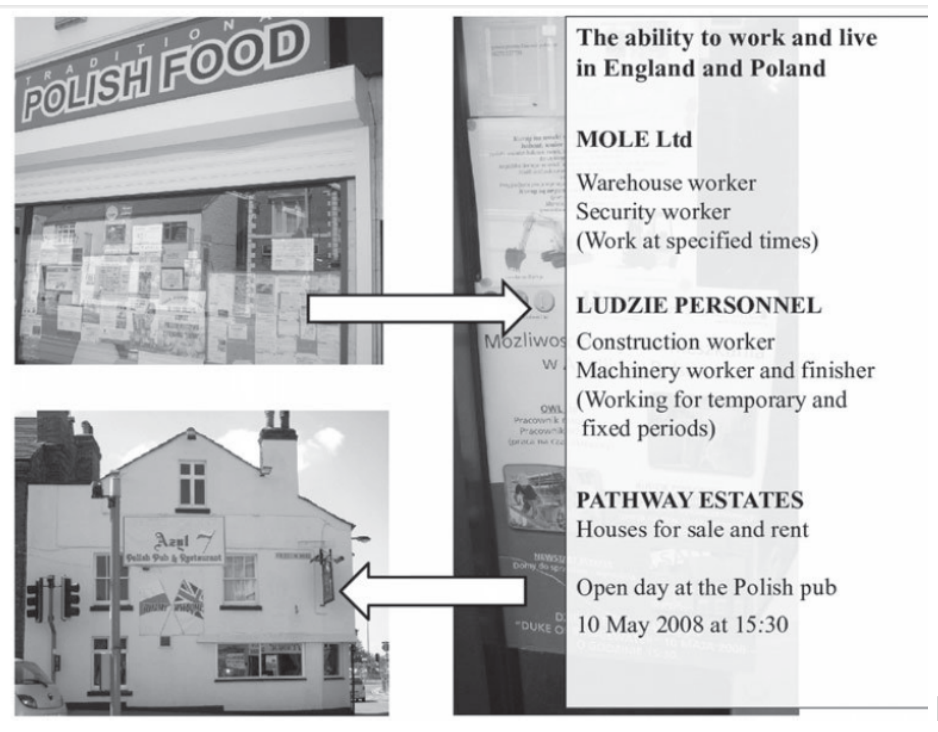

Figure 1. Poster in Polish Shop Window

With work and welfare information being circulated within this Polish institutional structure, the routes to construction work are presented as bridging out from these familiar key focal points in the Polish community. As we mentioned earlier, the jobs being offered may well be in neighboring counties, towns and cities, rather than local work in the borough. However, networks of support options (shared housing, group lifts to work etc.) are put in place through collaborations between recruitment and housing agents, such as this example of the open day held at the Polish pub.

\section{"The ability to work and live in England and Poland"}

The slogan on the poster "The ability to work and live in England and Poland" is significant in the context of pendulum migration and in terms of our discussion about living and working in the locality. For, as with the increased mobility of working lives in general, there is a stretching of work and home across two nations. We found evidence of this throughout the larger study of migrant workers, such as the case of ganger Artur, who we will discuss in a moment, who expressed his desire to bridge his work between England and Poland, using his current job, gaining a permanent contract with a main contractor in the UK, to eventually target a job with the contractor back in his native Poland. Brown (2006) expands on these decisions faced by migrant workers, suggesting that "now that they are here legally it is also far easier for Poles to travel back and forth between Poland and England, which means, ironically, that they can more easily take the risk of re-establishing themselves in Poland knowing that if things don't work out they can easily return" (p.49-50). 
Heath et al. (2011) outline some of the current directions within migration and family studies, with mainstream research often focusing on the discontinuity of economic migration and the "rupture, uprooting and loss of homeland" (Baldassar et al., 2007: 11), while the field of transnationalism has emphasised the active maintenance of ties with multiple locations and 'dual' or 'hybrid' identities. Interestingly, while we focus here on the mobilisation of ties and Polish allegiances in migrants' routes to construction work and up-skilling in the sector, the networks uncovered in our exploratory research were largely not based around the family/home ties per se, but rather on the activation of a form of 'mutual aid' based around common national aims fostered without prior personal acquaintance. This last statement, however, must be tempered with an acknowledgement of how significant new media and communication technologies have been in enabling (virtual) relationships between newly arriving Poles in the UK to be quickly grown and developed around these common aims. So it could be argued that these informal networks entail neither a loss of homeland nor a continuity of experience, but rather the forging of new relationships between Polish workers in a new country around common aims.

For instance, to draw on the last example, it might be assumed that the information avenues offered through a shop window would be limited to unofficial, unregulated, or 'cash in hand' jobs, but there are also informal links to training within this chain of information, to help workers get better jobs within construction. Consider another advert (in Polish) from the shop window, which offers training by experienced Polish workers in the industry for an "English license for forklifts and diggers on 2 days (Saturday, Sunday)", provided they have already achieved the "required minimum in the English language". While this is a good example of mutual aid in the sense that a skilled worker is selling his skill to the 'community' at a low cost, there is a higher degree of risk in the quality of the provision, and uncertainty in the veracity of links between such courses and in being able to gain (better) employment. Here networks of social contacts continue to grow, with community-based, localised, or 'bottom up' advertising offering services and training held often substantial distances outside the borough, in this case Leeds and London. Yet, this local community network of information in turn promotes mobility and opens networks not restricted to geographical boundaries, which loosens the ties between living and working in a locality.

As a consequence of the unpredictable and fluid nature of such economic migration patterns, Engbersen et al. (2010) stress the difficulty of policy makers in urban areas to develop "a sufficiently flexible infrastructure for temporary labour migration that is also supported by the local population" (p. 137). Indeed, it is arguably difficult for the host town and communities to plan ahead and draw clear lessons from, say, the informal, local and institutional networks created to support the influx of Polish workers in Crewe. However, as we will now argue, it does stress the importance of having more transparent recruitment processes, as informal employment has led to many of the deeply ingrained problems that the construction industry suffers from.

\section{Informal interpreter role and job-jumping (up the ladder)}

Fitzgerald (2007) reports how agencies played a leading role in first recruiting A8 migrant labour in the North West, with limited visible direct company or subcontractor recruiting in operation. However UCATT North West officials in this research indicated that, while agencies were initially used to source Polish workers to provide a 'first generation' of labour, a 'second generation' was often developed through a 'family and friends' network (p.7). This supports the wider understanding that low-skilled recruitment often takes place through informal networks at site level, with migratory chains dominating for sourcing foreign labour (e.g. Balch et al., 2004). Mutual aid (built on ethnic social relations), provided in the form of Poles now well-established in the UK construction industry (as foremen, superintendents etc.) acting as informal 'skill brokers', has provided some opportunities to help migrant workers move through the sector. However, we will now discuss how the distinct requirements of managing health and safety in the culturally diverse workplaces of construction sites, in this case following large-scale East European migration into the sector, has also provided another up-skilling opportunity for migrant workers.

Job-jumping from one construction employer to another, especially on the same construction site, is recognised as an informal migrant worker strategy to enable workers to "to stay on-site longer and thus demonstrate a broad array of skills to project superintendents who were in a position to potentially offer employment with a general contractor" (Iskander and Lowe, 2010: 141). Indeed, in the example of ex- 
agency worker, Artur, whom we will briefly discuss here, a key additional skill-set which appealed to the main contractor that offered him a permanent contract as ganger with them, was his language and cultural expertise along with his ties with the Polish communities.

Migrant workers employed through agencies and subcontractors can also develop skills and take on roles of additional responsibilities related to interpretation onsite, as another more informal route for up-skilling and progression in the sector. Our study found that the transition from construction agency migrant worker to permanent employee with the main contractor is rare, which is perhaps expected in an environment where permanent contracts are largely associated with the management and 'knowledge workers'. However, the recruitment of construction workers to new permanent posts on the projects we encountered were linked directly with their ability to contribute to the management and communication of health and safety on site e.g. the translation/ interpretation of health and safety material, site inductions etc. [2] This was the case for Artur, who we met on a large office site development in the North West of England. This was one of five sites which were visited intensively for three months during the fieldwork, which ranged from regularly shadowing workers on site, to interviewing workers independently. The two examples below are purposely selected to illustrate some of the contrasting experiences of Polish workers who have taken on such additional roles and responsibilities.

\section{Artur's story}

At nineteen years of age, Artur migrated to the UK from Poland with a friend, with no previous construction experience and few English language skills, and "was going to come just for three months and then go back to study [Financial Management in Poland]" but had remained with an agency for three construction jobs across the UK. There is reluctance from both workers and management to discuss the rare process of 'taking on' agency workers full time, although many main contractor projects in our study had a few workers who fitted into this category. If a migrant worker, employed by an agency, wants to negotiate a better deal (more responsibility, more pay, different work, or even this rare transition to permanent worker) it has to be done through the contractor on site. Yet, taking on extra responsibilities for extra pay, such as translating and/or leading other migrant workers in a gang, was a common way in which such informal roles were developed over the course of the construction projects we researched, as the health and safety manager for the main contractor who recruited Artur explains:

[Y]ou would come on the same rate initially. But I'd get you aside and say "do this and run the two of you, and I'll give you an extra pound an hour". ...I don't suppose it would... be of any favour for Agency to poach good men off them. But if you offer these agency guys permanent careers then they're going to snap it up, because it could be a day, it could be half a day, it could be a week, it could be two years, you know, there's nothing permanent with agencies and they know it.

(Health and safety manager, main contractor)

'Poaching' workers is a common activity in the construction industry, with supply relations complicated by the existence of labour-only-subcontracting (LOSC) and the persistence of self-employment, both deterring investment in training for the industry (See Chan et al., 2008). Yet, this is the type of situation in which Artur began to take on interpretation duties as part of his everyday work with other Polish personnel onsite as he up-skilled through the industry. A general foreman for the main contractor had a big influence on Artur's career and his choices in the UK construction industry - in a role as skills broker discussed above. Artur described how the foreman helped to get him employed "direct with [the main contractor]" and made him a ganger. The transition involved Artur leaving the agency (and telling them he was returning to Poland) before then signing a contract with the main contractor and returning to work on site: "we can tell the agency that we're going back to Poland, and then, straight back to [the main contractor]". This apparent 'leap of faith' - in leaving the agency before getting a permanent contract was not viewed as a problem by Artur, or seen as a risk, since he trusted the foreman's role in the process. It was in this post that the interpreter role became a major part of his job, "to help with everybody else", which included interpreting for workers over the phone, sometimes to communicate with workers on upper floors of the tower block rather than needing to bring them down to ground level for instruction.

In terms of the unofficial routes to work, this channel reaches further in that Artur suggested that he intends to follow the foreman to his next project. 
They [agency] always pay the same - they just give me 60p more... He [the foreman] was ringing the agency asking if we could get some more money - pay rise... He got a rise from $£ 5.35$ to $£ 6$ an hour... that's why I want to work with him. He's a good man ...sent me on more courses ... he sorted all the pay rises.

\section{(Artur, Ganger)}

This has parallels with phenomena identified by Mars $(1994 ; 195)$ in the catering industry, where "waiters may leave in groups soon after a head waiter has left, possibly to follow him to his new job where they can pick up their individual contracts with him where they left off". While cases such as this do not necessarily involve uprooting an entire gang or team, Artur indicated that he would move with his Polish friend Max, with whom he has always worked and lived with in the UK. While the following of main contractor staff to other jobs - by migrant general workers who have a close working relationship with them - seems far from rare, it is certainly common for teams of workers to move from job to job together and this was described by migrant workers on most sites which we visited.

However up-skilling by developing and diversifying roles and responsibilities on site was not always granting migrant workers a stronger foothold in the industry. We will now briefly discuss examples from our ethnographic research of workers engaging in health and safety via translation and interpretation work on site (paid, in one case, as a monthly safety award) and by taking on secondary (and sometimes conflicting) roles on site.

\section{Lukasz's story}

Lukasz is a Polish migrant who works as a traffic marshal for a logistics subcontractor on a large hospital project in England, and previously worked in Germany for three years as an English-speaking supervisor on construction sites. Lukasz has taken on a language function for extra pay. His extra responsibility officially involves running Polish safety and language sessions during training days and trades union 'Stand Down' days on the project. He also conducts site inductions for migrant workers struggling with the delivery in English, and has developed and planned the inductions over the project. He was involved in four series of evening general English language classes for migrant workers with a special unit on construction (funded through the main contractor and 'second-tier' contractors). It was through these sessions, and in later interviews with him, that we learnt that Lukasz had entered this job market for the experience of living and studying abroad, and was currently studying for a Masters part-time at college. The classes used only English tutors and so Lukasz was drafted in to help with interpretation within these sessions. He has also helped with the translation of documents, signs and posters to attend to emergent health, safety and welfare issues. Through his 'second role', Lukasz has also become an unofficial focal point for helping Polish workers onsite, with workers often coming to him with broader communication/cultural questions. This includes dealing with questions and problems which migrant workers encounter with documents in their on-and-off site lives which, as Lukasz comments, can be as diverse as explaining council forms to helping to fill in a fishing rod licence. This goes beyond health and safety, to welfare information, crosscutting the workers' cultural lives and working lives. The dual (or even conflicting) nature of Lukasz's roles was very apparent during an interview with him (arranged through the health and safety manager), when one of Lukasz's managers from logistics burst into the office shouting at him, and was adamant about him coming to fix kerbing in his section. This may reveal the way his health and safety interpretation and translation work needs to 'fit in' between and around his on-going trade work for the logistics contractor. This incident also highlighted the difficulties for the ethnographer of building and maintaining relationships with participants without in turn jeopardising their working roles and relationships which can cross various contractors and management on site. Lukasz explained that his current post enabled him to 'fit in' his work with his life off site (undertaking a Masters part-time), and that he could 'move up' the ladder to a better construction job if this was his key motivation. However this incident also hints at the tensions of such a balance given the shifting everyday demands and unpredictability of construction work. In a similar context, Trevena (2011b) highlights the inability of some migrants' who took on construction work (without having undertaken such physical labour before) to continue to support their original motivation of studying or other activities outside the workplace. As one Polish worker remarks, "if you work on the building site as a helper or lower level worker, you're just not 
up to it. Working and studying. It's just too difficult, at least for me ... intellectually I just died" (Trevena, 2011b).

\section{Migrant worker engagement in health and safety}

The role of informal translators and interpreters on site can be linked to main contractor policy to increase worker engagement in health and safety. For example, part of the Incident and Injury Free (IIF) industryled programme has been to attempt to involve all workers in the health and safety culture on site. Lukasz works on site for a large project over a five-year period where there is the time and the scope to implement such a scheme to give all workers full opportunity to contribute to the site health and safety culture. However, the increased level of (migrant) worker engagement in health and safety, in terms of language duties, needs to be closely monitored to check that it is a fair deal for all. This is to ensure that migrant workers with linguistic skills are not being taken advantage of in terms of providing, what would otherwise be, expensive interpretation and translation skills for free. Linked to this is the grouping of translation jobs with award schemes and prizes for promoting safe practice. Many sites implement a safety award scheme. However, the translation of health and safety documents is not what these safety awards were initially intended for. For example, one monthly safety award of $£ 100$ vouchers encourages workers to "get rewarded for safe actions". Yet, during our ethnographic research, we found that such safety award schemes often rewarded translation, such as a prize shared by two Polish workers for translating presentations and daily start booklets.

Of course, this translation work clearly contributes towards better site health and safety culture and performance, but could not really be cited as a 'safe action'. At one level this work can be seen as a longstanding feature of working in construction, "where erratic demand is a constant and where informal earnings form a high proportion of total rewards" (Mars, 1994: 195). It can also be a way to 'reward' workers within a process which can be difficult to negotiate better deals for the workers, as our discussion of agencies has already shown. However, the worry is that such a scheme might be sending out the wrong message about management attitudes to safe working on site. There is also the question of whether such informal translation of health and safety documentation is actually asking some migrant workers to take on too much responsibility for skills which they may not be trained or paid for, or which has little long-term impact on their routes to up-skilling, moving through the construction sector, or their other aspirations.

\section{Conclusion}

The routes and strategies employed by migrant workers in the construction industry reveal the enmeshed nature of the construction site and the wider networks through which employment is sought and negotiated. Through the closeness of our ethnographic approach we were able to appreciate the complexities and contingencies of the everyday working (and looking for work) lives of migrant construction workers.

Our research confirms that the sector's distinctly informal recruitment practices rely heavily on existing known networks. For newly arriving Polish migrant workers, this meant the development of temporary, ad hoc, and shifting networks of mutual aid and emergent chains of information and support within migrant communities. The 'local' networks which were outwardly structured around familiar Polish establishments were often, under closer inspection, found to be only loosely geographically-rooted to Crewe, and more in line with the fluid nature of economic migration towards following work and training, as is a feature of the sector more generally. Within this context, worker's language skills and cultural links can be seen as a distinct migrant resource which has enabled some workers to develop health and safety management roles and responsibilities. Indeed, translators and interpreters play a key role in enabling communication, acting as interlocutors between migrant workers and their indigenous counterparts. Arguably, official recognition of the practices of translation and interpretation is needed, especially in terms of formalising this role on site. As Iskander and Lowe (2010) argue in the context of the US construction sector, by making the informal routes and skill-development pathways of migrant workers visible, workers may be able to "open formal channels for skill-based advancement" which also "may provide a long-term solution to an intensifying industry-wide skill shortage" (p.143). 
Our wider research in this area has contributed to academic analysis of cultural diversity, intercultural communication and the health and safety of migrant labour (Pink et al., 2010; Tutt et al., 2013). As we have shown here, within this context there are key continuities between onsite and offsite processes, socialities and industry practices, which influence migrant workers' experiences of the sector, which need to be accounted for. While the focus of the ethnographer on individual lives may first appear narrow, it is the very depth and richness of the fieldwork material on the worker's lives (in contrast to the minimal details of workers on site held by main contractors, or of accidents in the sector) that enables us to pinpoint how industry-specific 'problems' of integrating migrant workers and managing health and safety in culturally diverse workplaces are set at the interface between the contingencies of everyday working lives and the wider political and economic inequalities that frame these.

\section{Endnotes}

[1] All names and identifiers have been anonymised in this article.

[2] Our ethnographic research identified informal interpreters and translators on site as providing a crucial communication channel between the site manager and migrant workers. The terms 'translate' and 'interpret' are often used interchangeably in everyday, non-technical language, but formal translation (written) and interpretation (oral) work are highly skilled and regulated professions. We found there to be little differentiation made between the two skills in practice on the construction sites we visited, with the same person often drafted in to do both jobs, meaning that there is a blurring of categories and a lack of appreciation of the different skill-sets. Consider also the host of different requirements within each role. For instance, the different skills involved in simultaneous interpreting (when the message is communicated in the target language as quickly as can be formulated) and consecutive interpreting (speaking after the source-language speaker has finished speaking), or between onsite interpreting (in person) and telephone interpreting. Most main contractors attempt to implement a ratio (typically '1-to-4') of working interpreters to 'non-English speakers', which is linked back to the Management of Health and Safety at Work Regulations 1999.

\section{References}

Anderson, B., Ruhs, M., Rogaly, B. and Spencer, S. (2006) Fair Enough? Central and East European migrants in low-wage employment in the UK, York: Joseph Rowntree Foundation.

Atkinson, P., Delamont, S., and Housley, W. (2007) Contours of Culture: Complex Ethnography and the Ethnography of Complexity. Lanham, MD: Rowman \& Littlefield.

Audit Commission (2007) Crossing Borders: Responding to the local challenges of migrant workers, Public Services National Report, January 2007, Case Studies, p. iii.

Baldasser, L., Baldock Vellekoop, C., Wilding, R. (2007) Families Caring Across Borders, Migration, Ageing and Transnational Caregiving. Basingstoke: Palgrave Macmillan.

Balch, A., Fellini, I., Ferro, A., Fullin, G., and Hunger, U. (2004) The Political Economy of Labour Migration in the European Construction Sector, in Bommes, M., Hoesch, K., Hunger, K. and Kolb, H. (eds) IMIS-Beiträge. Available at: www.imis.uni-osnabrueck.de/pdffiles/imis25.pdf

Bresnen, M. (2009) Living the dream? Understanding partnering as emergent practice, Construction Management and Economics, 27: 923-33.

Brown, B. (2006) Polish Mutual Aid, in Buonfino A., Mulgan G. (eds), Porcupines in Winter: The pleasures and pains of living together in modern Britain. Young Foundation: London, pp.47-50. 
Burrell, K. (2009) Migration to the UK from Poland: Continuity and Change in East-West European Mobility, in Burrell, K. (ed) Polish Migration to the UK in the 'New' European Union: After 2004, Aldershot: Ashgate, pp. 1-19.

CCA/ Irwin Mitchell (2009) Migrants' Workplace Deaths in Britain. Commissioned and Jointly Published by Irwin Mitchell and the Centre for Corporate Accountability.

Chan, P. and Dainty, A. (2007) Resolving the UK construction skills crisis: a critical perspective on the research and policy agenda, Construction Management and Economics, 25:4, 375-386.

Chan, P., Clarke, L. and Dainty, A. (2008) Staff shortages and immigration in construction, A paper prepared for the Migration Advisory Committee (MAC). Web published by the Migration Advisory Committee:

http://www.ukba.homeoffice.gov.uk/sitecontent/documents/aboutus/workingwithus/mac/239769/chanclarkedainty2008

Chan, P., Clarke, L. and Dainty, A. (2010) The Dynamics of Migrant Employment in Construction: Can Supply of Skilled Labour ever Match Demand? in Ruhs, M. and Anderson, B. (eds) Who Needs Migrant Workers?, Oxford University Press: Oxford, pp. 225-255.

Chappell, L., Sriskandarajah, D. and Swinburn, T. (2008) Building a New Home: Migration in the UK Construction Sector, Economics of Migration project, Working Paper 2, Institute for Public Policy Research. Available at: http://www.eelga.gov.uk/documents/Building-a-New-Home-migration\%20in\%20construction\%20sector.pdf

Currie, S. (2007) De-Skilled and Devalued: the labour market experience of Polish migrants in the UK following EU enlargement, International Journal of Comparative Labour Law and Industrial Relations, 23(1): 83-116.

Dainty, A.R.J., Gibb, A.G.F., Bust, P.D. \& Goodier, C.I. (2007) Health, safety and welfare of migrant construction workers in the south east of England, Institution of Civil Engineers, London.

Eade, J. (2007) Class and Ethnicity: Polish Migrant Workers in London: Full Research Report. ESRC End of Award Report, RES-000-22-1294. Swindon: ESRC.

Engbersen, G., Snel, E. and de Boom, J. (2010) 'A van full of Poles': Liquid migration from Central and Eastern Europe, in Black, R., Engbersen, G., Okolski, M., Pantiru, C. (eds), A Continent Moving West: EU Enlargement and Labour Migration from Central and Eastern Europe, IMISCOE Research: Amsterdam University Press, pp. 115-140.

Engbersen, G., Grabowska-Lusinska, I., Leerkes, A. (2011) The rise of liquid migration? Old and new patterns of migration after EU Enlargement, Interdisciplinary Conference on Migration, Economic Change, Social Challenge. April 6th-9th, 2011 University College London.

Favell, A. (2008), The New Face of East-West Migration in Europe, Journal of Ethnic and Migration Studies, 34 (5): 701-716.

Favell, A. and Recchi, E (2011), Social Mobility and Spatial Mobility, in Sociology of the European Union edited by Favell, A,. and Guiraudon, V. London: Palgrave, pp. 50-75.

Fitzgerald, I. (2007) Working in the UK: Polish migrant worker routes into employment in the North East and North West construction and food processing sectors. London: Trade Union Congress.

Flint, C. (2008) Modern migration: the Polish experience, Speech at the Polish Embassy, 20/11/2008. URL: http://www.fco.gov.uk/en/newsroom/latest-news/?view=Speech\&id=9490644

Gherardi, S. and D. Nicolini (2002), Learning the trade: a culture of safety in practice, Organization, 9: 191-223.

Gribling, M. and Clarke, L. (2006) Undeclared Labour in the Construction Industry: Country Report Great Britain. European Institute for Construction Labour Research.

Harvey, M. (2003) Privatization, fragmentation, and inflexible flexibilization in the UK construction industry, in Bosch, G. and Philips, P. (eds) Building Chaos: An international comparison of deregulation in the construction industry, Routledge: London, pp. 188-209.

Heath, S., McGhee, D., and Trevena, P. (2011) Lost in Transnationalism: Unravelling the Conceptualisation of Families and Personal Life Through a Transnational Gaze, Sociological Research Online, 16 (4), Published: 30 Nov 2011.

HSE (2010) Health and Safety Executive Topic Inspection Pack: Migrant Working: www.hse.gov.uk/foi/internalops/fod/inspect/migrantworker.pdf

HSE (2012) Reportable injury data collection practices confirmed through personal correspondence with HSE Construction Sector- Alistair Gibb, 13/11/12.

Hughes, B. (2008) Agenda: What worked for us, The Times, February 5th 2008. 
Iskander, N. and Lowe, N. (2010) Hidden Talent: Tacit Skill Formation and Labor Market Incorporation of Latino Immigrants in the United States, Journal of Planning Education and Research. 30 (2): 132-146.

Lett, L. and Smith, M. (2009) East meets West: The case of Polish expatriates in the UK, The International Journal of Human Resource Management. 20 (9):1864-1878.

Lillie, N. and Greer, I. (2007) Industrial Relations, Migration, and Neoliberal Politics: The Case of the European Construction Sector, Politics and Society, 35(4): 551-581.

Longhi, S. and Rokicka, M. (2012) European immigrants in the UK before and after the 2004 enlargement: Is there a change in immigrant self-selection?, ISER Working Paper Series, October 2012:

https://www.iser.essex.ac.uk/publications/working-papers/iser/2012-22

Mandic, S. (2008) Home-Leaving and its Structural Determinants in Western and Eastern Europe: An Exploratory Study, Housing Studies, 23 (4): 615-637.

Mars, G. (1994) Cheats at Work: An Anthropology of Workplace Crime. Aldershot: Dartmouth.

Marshall, N. and Bresnen, M. (2012) Where's the action: challenges of ethnographic research in construction, in Pink, S., Tutt, D. and Dainty, A. (eds) Ethnographic research in the construction industry. Routledge, Abingdon, UK, pp. 108-124.

McCollum, D. and Findlay, A. (2011) Trends in A8 migration to the UK during the recession, Population Trends. 145, 77-89.

McKay, S., Craw, M. and Chopra, D. (2006) Migrant Workers in England and Wales: An Assessment of Migrant Worker Health and Safety Risks. Report for the Health and Safety Executive (HSE) by the Working Lives Research Institute, London Metropolitan University, London.

Niedzwiedzki, D. (2008) Tolerance and Pluralism. Civic Components of Polish Pendulum Migrants' Identity in Belgium, European Review, 16 (4): 563-572.

ONS (2011), Polish People in the UK. Half a million Polish Residents, Migration Statistics Quarterly Report, August 2011 Release, Annual Population Survey (APS) - Office for National Statistics:

http://www.ons.gov.uk/ons/rel/migration1/migration-statistics-quarterly-report/august-2011/polish-people-in-theuk.html

Pemberton, S and Stevens, C. (2006) Supporting Migrant Workers in the North West of England, Merseyside Social Inclusion Observatory (MSIO) Policy Report: 3, October 2006.

Pink, S. (2008), "Re-thinking Contemporary Activism: From Community to Emplaced Sociality”, Ethnos, 73 (2): 163188.

Pink, S. (2009) Doing Sensory Ethnography, Sage, London.

Pink, S., Tutt, D., Dainty, A. and Gibb, A. (2010) "Ethnographic Methodologies for Construction Research: Knowing, Practice and Interventions in Migrant Worker's Health and Safety", Building Research \& Information. 38 (6): $647-659$.

Pink, S., Tutt, D. and Dainty, A. (eds.) (2012) Ethnographic research in the construction industry. London: Routledge.

Trevena, P. (2011a) Why do highly educated migrants go for low-skilled jobs? A case study of Polish graduates working in London, in Glorious, B. Grabowska-Lusinska, I. Kuvik, A. (eds) Mobility in Transition: Migration Patterns after EU enlargement. Amsterdam University Press.

Trevena, P. (2011b) Brain waste as threat to identity? Highly-educated migrants in low-skilled jobs. NORFACE Migration Network Conference, Migration: Economic Change, Social Challenge Conference, University College London, 6-9 April 2011.

Tutt, D., Dainty, A. Gibb, A., and Pink, S. (2010) "Migrant Construction Workers and Health \& Safety Communication", ConstructionSkills Report. King's Lynn, Norfolk: CITB ConstructionSkills:

http://www.cskills.org/sectorskills/researchfromssc/migrant-workers-health-andsafety.aspx

Tutt, D., Pink, S., Dainty, A. and Gibb, A. (2013, in press) “'In the air' and below the horizon: Migrant workers in UK construction and the practice based nature of learning and communicating OHS", Construction Management \& Economics.

UCATT (2012) False self-employment, UCATT (Union of Construction, Allied Trades and Technicians) website. https://www.ucatt.org.uk/false-self-employment 